Vol 1 No 12020 Juli 2020

Jurnal AlphaEuclidEdu

Received: 08/07/2020; Revised: 29/07/2020; Accepted: 30/07/2020

\title{
HAMBATAN EPISTEMOLOGI PEMAHAMAN KONSEPTUAL BERDASARKAN TAKSONOMI SOLO PADA SISWA
}

\author{
${ }^{1}$ Utami, Zhafirah Atiqah, ${ }^{2}$ Sugiatno, ${ }^{3}$ Ijuddin, Romal \\ ${ }^{123}$ Pendidikan Matematika FKIP Universitas Tanjungpura Pontianak \\ zapzaputami@gmail.com
}

\begin{abstract}
This study aims to explain and describe the epistemological obstacle of students' mathematical conceptual understanding based on the SOLO taxonomy at MTs Negeri 2 Pontianak. This research uses a descriptive qualitative method with a survey form. The subjects of this research is 35 students in class VIII F MTs Negeri 2 Pontianak. Data collection techniques that used were test and and non-test. Data collection tools that used were conceptual understanding tests and interview. The results of data analysis from this study indicate that the epistemological obstacle of students' mathematical conceptual understanding based on the SOLO taxonomy from 35 students is $40 \%$ of students are in level 0 (prestructural); $11.43 \%$ of students are in level 1 (unistructural); $20 \%$ of students are in level 2 (multistructural); $25.71 \%$ of students are in level 3 (relational); and $2.86 \%$ of students are in level 4 (extended abstract). The obstacle of students that have at level 0 are all of conceptual understanding' indicator. Students at level 1 and 2 have obstacles in indicators 2, 3, and 4. Students at level 3 have obstacles in indicators 2 and 4. Students at level 4 have obstacles in indicator 4.
\end{abstract}

Keywords: Epistemological obstacle, Mathematical Conceptual Understanding, SOLO Taxonomy

\section{Pendahuluan}

Pemahaman konseptual matematis merupakan kemampuan yang perlu dimiliki siswa dalam proses pembelajaran matematika. Hal ini ditegaskan oleh suatu pandangan untuk Matematika Sekolah dalam National Council of Teacher of Mathematics [NCTM] (NCTM, 2000) yang mengungkapkan bahwa "Siswa harus aktif dalam mengontruksi pengetahuan baru dari pengetahuan dan pengalaman sebelumnya serta dapat belajar matematika dengan pemahaman.”. Karena itu pemahaman konseptual matematis yang baik dibutuhkan siswa dalam mempelajari matematika lebih lanjut.

Pemahaman konseptual siswa dalam menyelesaikan masalah matematika apabila dapat dikontrol dengan benar maka akan menunjang siswa tersebut dalam mempelajari matematika sehingga dapat mempengaruhi hasil belajarnya. Tinggi rendahnya kemampuan siswa menjadi salah satu sebab tinggi rendahnya pula hasil belajar siswa pada pembelajaran matematika. Peraturan Menteri Pendidikan dan Kebudayaan (Permendikbud) Republik Indonesia Nomor 58 Tahun 2014, menyebutkan bahwa salah satu tujuan dari pembelajaran matematika ialah mengerti dan paham akan konsep matematika, hal ini meliputi kompetensi dalam menjelaskan hubungan antar konsep dan menggunakan konsep maupun algoritma secara akurat, luwes, tepat, dan efisien dalam menyelesaikan suatu permasalahan.

Namun pada kenyataannya di lapangan, hasil dari pembelajaran matematika pada siswa masih rendah. Hal ini terlihat dari hasil ulangan harian kelas VIII F MTs Negeri 2 Pontianak. Dari 36 siswa, persentase siswa yang belum mencapai Standar Kriteria Ketuntasan Minimal (KKM $\geq 75)$ sebesar 77,78\% atau sebanyak 28 siswa. Dari data tersebut dapat dilihat bahwa hasil belajar mata pelajaran matematika siswa kelas VIII F MTs Negeri 2 Pontianak masih tergolong rendah, hal ini diperkuat oleh pendapat Djamarah dkk (2000: 18) jikalau pelajaran yang telah diajarkan kurang dari 65\% dikuasai oleh siswa maka persentase keberhasilan/ketuntasan siswa dalam mata pelajaran tersebut tergolong rendah.

Rendahnya hasil belajar siswa tersebut pada dasarnya berasal dari kesulitan yang dialami siswa dalam membangun konsep materi yang diajarkan. Siswa belum bisa memahami definisi dari Relasi dan Fungsi, terbukti ketika ada soal latihan yang meminta diberikan contoh relasi yang merupakan fungsi, beberapa siswa menjawab dengan jawaban yang kurang tepat seperti memasangkan 1 anggota domain dengan 2 anggota kodomain, selain itu ada pula yang tidak memasangkan anggota domain dengan tepat 1 anggota kodomain. Padahal berdasarkan definisi, fungsi dari A (pertama) ke B (kedua) adalah hubungan/relasi khusus yang memasangkan semua/setiap anggota himpunan pertama ke tepat satu anggota himpunan kedua. Kemudian masih banyak terdapat kesulitan dalam menyelesaikan soal yang lain, diantaranya siswa belum mampu menemukan 
Vol 1 No 12020 Juli 2020

Jurnal AlphaEuclidEdu

hubungan antara dua buah himpunan (yaitu ketidakmampuan menerapkan ide-ide untuk situasi baru), tidak dapat melanjutkan proses penyelesaian (yaitu ketidakmampuan siswa menghubungkan makna dengan hasil), serta tidak dapat menyelesaikan soal dengan menyertakan cara eliminasi maupun subsitusi (belum mampu mengaitkan antara ide-ide yang lama dengan ide-ide yang baru). Hal tersebut mengindikasikan bahwa pemahaman konseptual matematis siswa dalam materi relasi dan fungsi masih rendah. Ketidakmampuan siswa dalam memahami dan menunjukkan indikator pemahaman konseptual juga dilihat dari bagaimana respon siswa pada saat di dalam kelas. Ketika guru menjelaskan di depan, banyak siswa yang masih kesulitan bahkan tidak mampu untuk memberikan respon terhadap apa yang mereka terima. Salah satu diantaranya adalah saat guru memberikan pertanyaan tentang materi relasi dan fungsi yang sudah dijelaskan, respon siswa hanya berupa diam dan tidak mampu menjawab apa yang ditanyakan guru. Sehingga hal ini juga menujukkan bahwa pemahamam konseptual siswa masih tergolong rendah dan masih mengalami kesulitan dalam menyelesaikan soal.

Menurut Rasmania (2018) kesulitan belajar ialah suatu situasi yang gejalanya terdapat hambatan dalam proses pembelajaran sehingga tujuan yang diinginkan tidak tercapai dengan sebagaimana mestinya. Sehingga dapat disimpulkan bahwa kesulitan belajar adalah suatu keadaan yang dapat menyebabkan siswa tidak dapat mengikuti proses pembelajaran secara maksimal disebabkan oleh faktor tertentu yang dapat menghambat siswa dalam belajar sehingga berdampak pada rendahnya prestasi akademik sehingga apabila ditelurusi secara hirarkis kesulitan belajar disebabkan oleh adanya hambatan belajar.

Hambatan yang dirasakan oleh siswa ini lebih dikenal dengan sebutan learning obstacle. Brousseau (1997: 86) mengungkapkan bahwa learning obstacle dikarekan oleh tiga aspek, yaitu hambatan ontogeni (kesiapan terkait mental belajar), didaktis (model pembelajaran atau bahan ajar guru), dan epistemologi (pengetahuan yang terbatas yang dimiliki siswa). Menurut Duroux (dalam Suryadi, 2010: 11) pengetahuan yang hanya terbatas pada konteks tertentu yang dimiliki oleh seseorang merupakan pengertian dari epistemological obstacle. Jika seseorang itu dihadapkan pada hal yang baru, maka ia akan mengalami hambatan dalam menggunakan pengetahuan yang telah ia miliki. Berdasarkan hasil tanya jawab dalam wawancara dan observasi sekolah yang dilakukan peneliti pada kegiatan PPL di MTs Negeri 2 Pontianak, guru akan meremidi siswa yang hasil belajarnya belum mencapai KKM. Apabila nilai dari remidi siswa masih rendah, terkadang guru langsung memberikan tugas di rumah sehingga nilai siswa menjadi 75 sesuai dengan KKM yang berlaku. Guru tidak mencoba mencari akar permaslahan yang dialami siswa untuk mengatasi permasalahan tersebut. Hal demikian dilakukan guru dikarenakan ketika dalam menyampaikan materi pelajaran kurang menarik siswa untuk bertanya dan menjawab pertanyaan, siswa lebih ke arah diam karena merasa takut jika salah dalam menyampaikan jawaban/respon.

Adapun penyebabnya yaitu guru disana masih menggunakan taksonomi Bloom yang belum menyediakan cara yang kuat namun sederhana untuk mendeskripsikan bagaimana hasil belajar siswa dan mengkhususkan respon siswa terhadap masalah. Berangkat dari masalah tersebut maka perlu adanya kajian dari sisi lain selain taksonomi yang sedang berlaku di sistem pendidikan Indonesia saat ini yang bisa mengklasifikasikan respon nyata dari siswa.

Untuk mengklasifikasikan respon nyata dari siswa guru dapat menganalisis hambatan yang dilakukan oleh siswa melalui respon (jawaban) dari pembagian soal. Kemudian untuk mengetahui kualitas jawaban(respon) siswa bisa dianalisis dengan mempergunakan taksonomi SOLO. Hal ini sejalan dengan John Pegg (1992) yang menyatakan bahwa "Model Taksonomi SOLO berakar pada analisis respon/jawaban terhadap pertanyaan yang diajukan dalam berbagai bidang/topik. Fokus yang dianalisis yaitu untuk menentukan seberapa baik suatu pelajaran yang telah dipelajari."

Kemampuan kognitif yang tampak yaitu tingkah laku sebagai sebab terjadinya proses berpikir seseorang. Dari tingkah laku tersebut maka dapat ditarik kesimpulan terikait kemampuan kognitifnya. Kita tidak akan dapat melihat secara langsung proses berfikir yang terjadi pada seorang siswa yang dihadapkan pada sejumlah pertanyaan, namun kita dapat mengetahui kemampuan kognitifnya dari jenis dan kualitas respon yang diberikan. Biggs dan Collis (1982) mengungkapkan bahwa tiap tahap kognitif terdapat respon yang sama dan makin meningkat dari yang sederhana hingga ke yang abstrak. Teori mereka disebut Structure of the Observed Learning Outcome (SOLO) yaitu struktur dari hasil belajar yang diamati. Taksonomi ini digunakan untuk mengorganisasikan kemampuan siswa dalam merespon suatu masalah menjadi lima level berbeda dan bersifat hirarkis yaitu prastruktural, unistruktural, multistruktural, relasional, dan extended abstract. Siswa pada level prastruktural tidak dapat menyelesaikan tugas yang diberikan atau menyelesaikan soal dengan data akurat. 
Vol 1 No 12020 Juli 2020

Jurnal AlphaEuclidEdu

Siswa pada level unistruktural dapat menggunakan satu buah informasi dalam menjawab/merespons suatu masalah. Siswa pada level multistruktural dapat menggunakan beberapa buah informasi pada soal namun tidak dapat mengaitkannya secara bersamaan. Siswa pada level relasional dapat mennyelaraskan beberapa buah informasi yang terpisah untuk menghasilkan penyelesaian dari soal yang diberikan. Siswa pada level extended abstract dapat menemukan prinsip/bentuk umum dari data terpadu yang dapat diaplikasi untuk kondisi baru (konsep tingkat tinggi).

Sebuah kesalahan yang tidak tersingkap berakar dari pikiran siswa, oleh sebabnya hal itu dapat menjadi risiko terbesar dalam pembentukan pengetahuan siswa (Legutko dalam Manibuy) sehingga hal tersebut apabila dapat diatasi dengan baik maka akan berguna bagi siswa dan guru.

Guru diharapkan dapat mengetahui hambatan siswa dalam menyelesaikan soal bentuk uraian materi Relasi dan Fungsi dengan menganalisis hasil belajar siswa tersebut. Selanjutnya informasi tersebut bisa dipergunakan untuk merancangan suatu variasi pembelajaran atau pembelajaran alternatif yang bisa dipergunakan untuk menyingkirkan hambatan belajar siswa sehingga dapat meminimalisir terjadinya kesalahan siswa.

Berdasarkan pemaparan latar belakang di atas, penelitian mengenai "Hambatan Epistemologi Pemahaman Konseptual Siswa Berdasarkan Taksonomi Solo Pada Siswa SMP” menjadi hal suatu hal yang menarik untuk diteliti.

\section{Metode Penelitian}

Jenis Penelitian deskriptif adalah metode yang dipergunakan dalam penelitian ini dengan bentuk penelitian survei. 35 siswa kelas VIII F MTs Negeri 2 Pontianak yang menjadi subjeknya.

Adapun tahapan yang dilaksanakan yaitu mulai dari persiapan, yakni melakukan observasi saat PPL, menyusun proposal penelitian, melaksanakan seminar proposal/desain penelitian, dan melakukan revisi dari hasil seminar. Selanjutnya yaitu menyusun instrumen yang akan dipergunakan untuk penelitian. Adapun instrumen yang digunakan dalam penelitian ini yaitu tes pemahaman konseptual matematis siswa dan pedoman wawancara. Kemudian tes tersebut diuji coba secara terbatas untuk memvalidasi kelogisan tes yang telah disusun. Adapun uji coba terbatas dilakukan pada beberapa siswa SMP kelas VII dan IX.

Setelah melakukan uji coba terbatas, dilakukan validasi instrumen oleh dosen matematika Fakultas Keguruan dan Ilmu Pendidikan Universitas Tanjungpura dan guru mata pelajaran matematika MTs Al-Jihad, masing-masing sebanyak satu orang. Revisi instrumen dilakukan jikalau hasil validasi tidak valid. Setelah dilakukan validasi, maka tes tersebut diuji cobakan pada siswa kelas VIII A MTs Al-Jihad Pontianak. Setelahnya, peneliti melakukan penelitian di kelas VIII F MTs Negeri 2 Pontianak. Hasil dari penelitian yang telah dilakukan kemudian diolah dengan tujuan agar dapat menjelaskan dan mendeskripsikan hambatan epistemologi pemahaman konseptual matematis siswa berdasarkan taksonomi SOLO di SMP. Teknik pengumpulan data yang digunakan ialah teknik tes dan non tes. Teknik tes berupa soal sedangkan teknik non tes berupa wawancara.

Kemudian tes pemahaman konseptual dan pedoman wawancara peneliti gunakan sebagai alat pengumpul data dalam penelitian ini. Adapun langkah-langkah yang digunakan untuk teknik analisis data yaitu: (1) Memberikan satu lembar yang berisi 4 soal mengenai tes pemahaman konseptual matematis kepada 35 siswa kelas VIII F MTs Negeri 2 Pontianak (2) Mengoreksi kemudian menyimpulkan kualitas respon setiap siswa kedalam level taksonomi SOLO (3) Memilih 5 orang perwakilan dari tiap level untuk diwawancarai (4) Melakukan analisis terhadap 4 soal pemahaman konseptual matematis dan hasil tanya-jawab dari wawancara untuk mendapatkan informasi bagaimana hambatan pemahaman konseptual yang dialami siswa pada masingmasing level (5) Mendeskripsikan hasil analisis terhadap hasil tes pemahaman konseptual dan wawancara yang telah dilaksanakan untuk menarik beberapa kesimpulan.

\section{Hasil Penelitian dan Pembahasan}

\subsection{Hasil Penelitian}

Setelah dilaksanakannya penelitian maka dikoreksilah hasil jawaban dari 35 siswa, kemudian menyimpulkan kualitas jawaba/respon masing-masing siswa yang dikaji dari taksonomi SOLO. Berikut disajikan hasil jawaban siswa berdasarkan indikator pemahaman konseptual 
Vol 1 No 12020 Juli 2020

Jurnal AlphaEuclidEdu

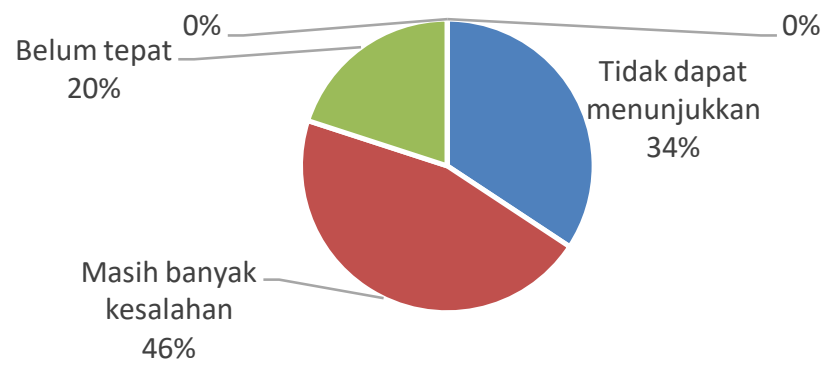

Gambar 1. Hasil Jawaban Berdasarkan Indikator Dapat Menunjukkan Contoh dan Bukan Contoh Konsep

Berdasarkan Gambar 1 diatas diperoleh sebesar 34,3\% siswa tidak dapat menunjukkan contoh dan bukan contoh. 45,7\% siswa dapat menunjukkan contoh dan bukan contoh tetapi banyak kesalahan. 20\% dapat menunjukkan contoh dan bukan contoh tetapi belum tepat.

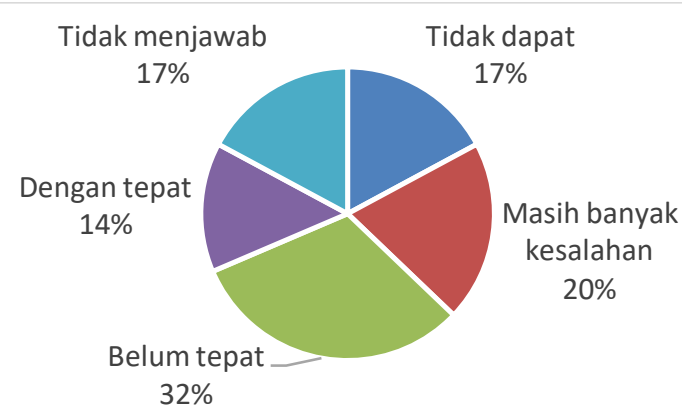

Gambar 2. Hasil Jawaban Berdasarkan Indikator Dapat Mengaplikasikan dan Mengolah Ide-Ide Untuk Situasi Baru

Berdasarkan Gambar 2 diatas diperoleh sebesar 17,1\% siswa tidak dapat mengaplikasikan dan mengolah ide-ide untuk situasi baru. 20\% siswa dapat mengaplikasikan dan mengolah ide-ide untuk situasi baru tetapi masih banyak kesalahan. 31,4\% siswa dapat mengaplikasikan dan mengolah ide-ide untuk situasi baru tetapi belum tepat. $14,3 \%$ siswa dapat mengaplikasikan dan mengolah ide-ide untuk situasi baru dengan tepat. $17,1 \%$ siswa tidak menjawab.

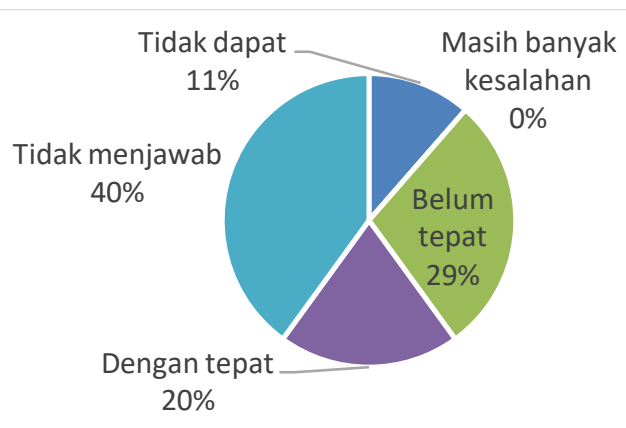

Gambar 3. Hasil Jawaban Berdasarkan Indikator Menghubungkan Makna Dengan Hasil

Berdasarkan Gambar 3 diatas, diperoleh sebesar 11,43\% siswa tidak dapat mengubungkan makna dengan hasil. 28,57\% siswa dapat menghubungkan makna dengan hasil tetapi masih belum tepat. $20 \%$ siswa dapat menghubungkan makna dengan hasil $40 \%$ siswa tidak menjawab soal. 
Vol 1 No 12020 Juli 2020

Jurnal AlphaEuclidEdu

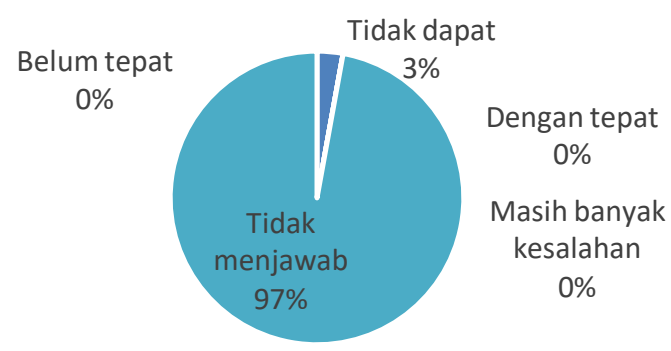

Gambar 4. Hasil Jawaban Berdasarkan Indikator Belum Mampu Mengaitkan Antara Ide-Ide Yang Lama Dengan Ide-Ide Yang Baru

Berdasarkan Gambar 4 diatas, diperoleh sebesar 2,85\% siswa tidak dapat mengaitkan antara ide-ide yang lama dengan ide-ide yang baru dan $97,15 \%$ siswa tidak menjawab soal. Hasil tes pemahaman konsepual siswa pada tiap level taksonomi SOLO dapat dilihat pada gambar berikut

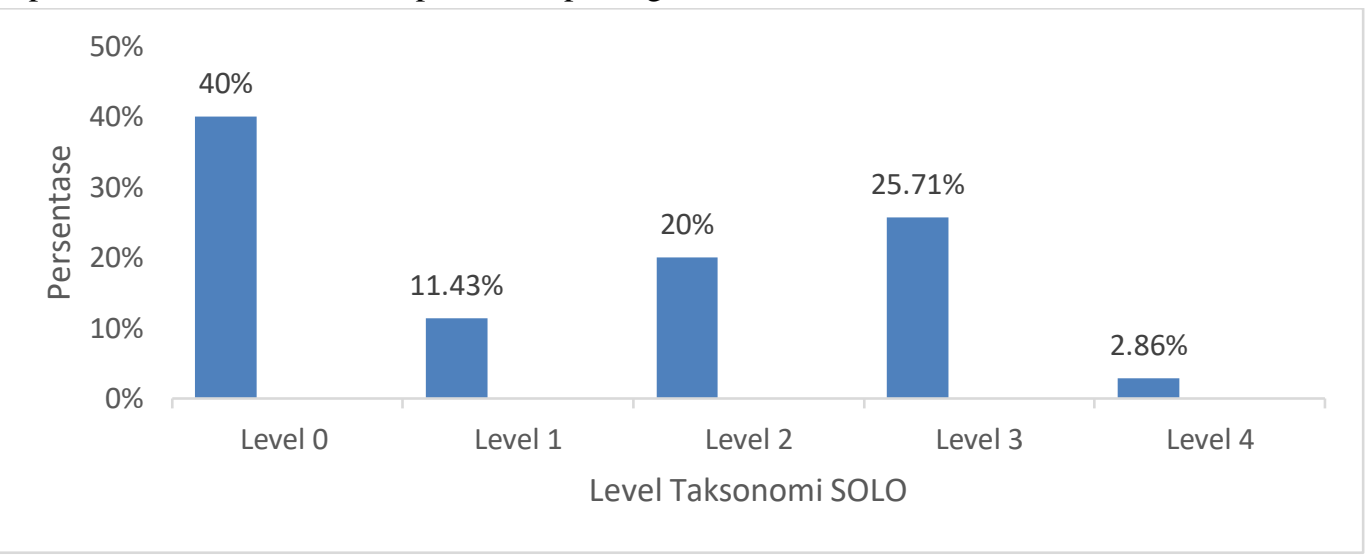

Gambar 5. Ketercapaian Siswa Tiap Level Taksonomi SOLO pada Tes Pemahaman Konseptual

\subsection{Pembahasan}

\subsubsection{Analisis Hasil Tes Tertulis}

Berikut adalah pembahasan hambatan epistemologi pemahaman konseptual matematis siswa dari masing-masing level taksonomi SOLO.

Berdasarkan Gambar 5. Siswa pada level prastruktural, presentase yang diperoleh yaitu $40 \%$ artinya ada banyak siswa yang berada pada level ini yang memerlukan kematangan dalam menganalisa maksud soal. Siswa tidak mampu menjawab hampir semua soal yang diberikan. Pada lembar jawaban, siswa mengalami keterbatasan untuk berpikir dalam menyelesaikan keempat soal yang mengacu pada keempat indikator pemahaman konseptual.

Hambatan yang dialami siswa dalam menyelesaikan soal dikarenakan siswa merasa lupa dan pada akhirnya tidak paham dengan apa yang diminta soal. Dapat dilihat pada sepenggal wawancara dengan siswa S9, seperti dibawah ini

$\mathrm{P}$ : Bisa membedakan yang mana contoh fungsi dan bukan contoh fungsi nda?

S9 : Bisa bu.

$\mathrm{P}$ : Bagaimana?

S9 : Kalo fungsi yang penting himpunan A punya pasangan bu, tapi satu jak. Kalo himpunan B ngikut jak dia. Yang bukan fungsi, banyak cabangnya bu.

$\mathrm{P}$ : Kira-kira sudah sesuai belum dengan jawaban Dhifa di kertas jawaban?

S9 : Hehe. Kemarin lupa bu.

$\mathrm{P}$ : Oke, kalau nomor 2, 3, 4. Kenapa tidak dijawab? 
Vol 1 No 12020 Juli 2020

Jurnal AlphaEuclidEdu

S9 : Saya nih bisa mengerjakan kalau ada contoh cara ngerjakannya bu. Misal liat buku dulu, nanti baru bisa saya ikutkan cara-caranya.

Siswa S9 mengatakan bahwa ia merasa tidak paham dengan cara menyelesaikan soal apabila tidak melihat contoh yang ada dibuku atau minimal dijelaskan langkah-langkah penyelesaiannya terlebih dahulu. Sehingga dapat diketahui pada level ini siswa mengalami hambatan dalam menuliskan infotmasi yang diketahui dalam soal, memahami maksud soal, dan hambatan dalam menganalogikan maksud pada soal karena belum paham dengan konsep relasi dan fungsi.

Berdasarkan Gambar 5, tampak bahwa siswa level unistruktural, presentase yang diperoleh yaitu $11,43 \%$. Pada lembar jawaban, siswa yang masuk dalam level ini sudah dapat menuliskan informasi yang di ketahui dan di tanyakan serta dapat mencatat formula matematika/rumus yang perlu dipakai untuk menyelesaikan soal namun belum dapat mengaplikasikan dengan apa yang diinginkan pada soal. Walaupun begitu siswa masih mengalami hambatan yang menyebabkan ia masih melakukan kesalahan

Hal yang menjadi hambatan siswa level ini dapat dilihat pada sepenggal wawancara dengan siswa S3, sebagai berikut.

$\mathrm{P}$ : Dari keempat soal boleh tunjukkan yang paling sulit?

S3 : Nomor 2, 3, dan 4 bu

$\mathrm{P}$ : Alasannya?

S3 : Kalau nomor 2 tuh, saya nda tau harus ngubungkan yang A dengan B gimana. Jadi saya liat jawaban kawan disebelah, tapi tetap nda ngerti. Kalau nomor 3 bingung cara nyari k, kan $\mathrm{f} 4$ belum ada nilainya. Yang nomor 4 sama sekali nda tau bu.

Siswa mengatakan kalau ia masih bingung bagaimana cara untuk menemukan relasi yang tepat agar dapat menghubungkan dua buah himpunan sehingga relasi tersebut dapat disebut fungsi. Selain itu siswa juga masih belum lancar mencari nilai fungsi jika hanya diberikan notasi fungsi saja pada soal dan siswa juga merasa kesulitan karena tidak pernah menyelesaikan soal yang diberikan sebelumnya.

Berdasarkan Gambar 5 tampak bahwa siswa level mutlistruktural, presentase yang diperoleh yaitu $20 \%$, lebih tinggi daripada level sebelumnya. Pada lembar jawaban, dapat terlihat siswa yang tergolong di level ini sudah bisa menafsirkan soal dengan baik, memahami maksud soal, apa yang isi soal, dan juga mengetahui tahapan-tahap yang perlu diselesaikan walaupun jawaban yang diberikan masih belum tepat/benar.

Hambatan yang dialami siswa dalam menyelesaikan soal dikarenakan siswa tersendat untuk melanjutkan penyelesaiannya sehingga menyebabkan siswa menjadi tidak paham dalam menyimpulkan jawabannya. Dapat dilihat dari hasil wawancara dengan siswa berkode S32

$\mathrm{P}$ : Soal nomor berapa aja yang paling sulit?

S32 : Ada beberapa yang nda bisa dikerjakan, tapi yang paling susah nomor 4 bu

$\mathrm{P}$ : Soal yang mana yang nda bisa sasa kerjakan?

S32 : Soal nomor 2 lupa gimana cara buat rumus fungsinya bu.

$\mathrm{P}$ : Oh, tapi sudah hampir benar jawabannya. Kalau nomor 3 kira-kira udah benar belum?

S32 : Ha kalau nomor 3 saya cuma bisa masukkan nilai 4 jak bu ke yang 3 kuadrat kurang itu tu bu. Kalau nyari k nya nda tau bu.

$\mathrm{P}$ : Sebelumnya udah pernah ngerjakan soal seperti ini?

S32 : Pernah nda salah dikasi contoh same bapak bu. Tapi lupa gimana.

$\mathrm{P}$ : Kalau kesulitan nomor 4 ?

S32 : Nda paham soalnya bu.

Siswa mengatakan bahwa ia merasa lupa dan belum paham pada materi relasi dan fungsi. Siswa juga tidak pernah mengecek dan mengulang kembali materi yang sudah ia dapatkan pada jam pelajaran matematika.

Berdasarkan Gambar 5, presentase yang diperoleh pada level relasional sebesar $25,71 \%$. Bisa dikatakan siswa yang masuk level ini ialah siswa yang tidak banyak melakukan kesalahan. Maksudnya siswa sudah mampu menunjukkan beberapa indikator dengan baik namun kurang cermat dalam menyelesaikan soal terakhir yaitu nomor 4, selain itu siswa masih asing dalam mengasah beberapa materi yang memiliki keterkaitan.

Hambatan tersebut dapat dilihat pada sepenggal wawancara dengan siswa S26 sebagai berikut: 
Vol 1 No 12020 Juli 2020

Jurnal AlphaEuclidEdu

$\mathrm{P}$ : Soal nomor berapa yang paling sulit diantara keempat soal?

S26 : Nomor 4 bu

$\mathrm{P}:$ Kenapa?

S26 : Kami baru belajar SPLDV sekitar awal bulan bu, jadi nda paham betul caranya. Waktu untuk tes kemarin pun kurang rasenye bu.

$\mathrm{P}$ : Oh begitu, kalau soal nomor 2?

S26 : Bisa bu, tinggal pasangkan jak yang A ke B.

$\mathrm{P}$ : Coba lihat lagi, masih ingat konsep fungsi?

S26 : Oh iya, kan harus 1 pasangan. Pantas saya bingung mau nulis rumus fungsinya

Siswa mengatakan bahwa bisa menyelesaikan soal apabila diberikan durasi lebih dikarenakan baru menerima materi SPLDV. Selain itu siswa merasa lupa tentang konsep fungsi yaitu harus memasangkan semua anggota domain dengan tepat satu anggota kodomain sehingga siswa tersebut mengalami kebingungan saat akan menentukan apa yang diinginkan oleh soal.

Berdasarkan Gambar 5, siswa pada level extended abstract memperoleh persentase sebesar $2,86 \%$. Angka yang sangat kecil apabila dibandingkan dengan level yang lain. Artinya, sangat sedikit siswa yang mampu mencapai level ini. Pada level ini, siswa sudah dapat menunjukkan keempat indikator pemahaman konseptual dengan baik. Namun tidak dapat dipungkiri bahwa siswa juga masih mengalami hambatan pada beberapa indikatornya.

Hambatan tersebut dapat diketahui dari hasil wawancara pada siswa berkode S6 sebagai berikut

$\mathrm{P}$ : Kenapa menjawab 14 ?

S6 : Saya coba-coba jak bu. f(-3) kan sama dengan 15, berarti -3 kali -5. Trus f(3) sama dengan 9, berarti 3 kali 3. Abis itu masukkan nilai yang ditanya, kan -2 sama 2 tuh bu. -2 kali -5 trus 2 kali 2. Barulah ditambahkan dapat 14.

$\mathrm{P}$ : Masih ingat SPLDV?

S6 : Lupa-lupa ingat bu.

Siswa mengatakan bahwa dirinya hanya mencoba-coba memasukkan nilai yang diketahui lalu dicobakan lagi dengan nilai yang ditanya. Namun ketika ditanya konsep SPLDV, siswa mengaku lupa karena tidak terbiasa latihan soal seperti itu. Namun siswa mengatakan bahwa untuk menjawab soal nomor 4 ia teringat akan konsep pola bilangan yang diajarkan pada BAB pertama. Sehingga bisa dikatakan siswa pada level ini sudah mampu mengaitkan antara ide-ide yang lama dengan ide-ide yang baru, walaupun belum tepat sasaran.

Berdasarkan hasil tes yang diberikan kepada 35 siswa kelas VIII F MTs Negeri 2 Pontianak, sebagian siswa mengalami hambatan epistemologi pemahaman konseptual. Siswa pada level terendah yakni level prastruktural mengalami hambatan pada semua indikator pemahaman konseptual, sedangkan siswa pada level tertinggi yakni extended abstract hanya mengalami hambatan pada indikator keempat saja. Hal tersebut memberikan bukti bahwa hambatan pemahaman konseptual yang dialami siswa dari lima level berbeda itu bersifat hirarkis. Seperti yang sudah dijelaskan Kifowit, siswa dikatakan menunjukkan pemahaman konseptual dengan baik apabila siswa sudah mampu (1) Menunjukkan yang mana yang merupakan contoh konsep dan yang mana yang bukan contoh konsep, (2) Mengaplikasikan dan mengolah ide-ide untuk situasi baru, (3) Menghubungkan makna dengan hasil, (4) Mengaitkan antara ide-ide yang lama dengan ide-ide yang baru. Dalam penelitian ini level prastruktural memiliki presentase yang lebih tinggi daripada level yang lain, hal ini menunjukkan bahwa siswa mengalami ketidakutuhan pengetahuan mengenai konsep relasi dan fungsi sehingga mengakibatkan siswa mengalami keterbatasan untuk berpikir dalam menyelesaikan soal-soal yang mengacu pada indikator pemahaman konseptual. Bahkan siswa yang berada pada level tertinggi, yaitu level extended abstract, hanya mampu menunjukkan 3 indikator saja. Siswa pada level ini belum mampu menunjukkan indikator keempat yaitu mampu belum mampu mengaitkan antara ide-ide yang lama dengan ide-ide yang baru. Siswa mengaku lupa dan bahkan tidak kepikiran dengan konsep lain yang dapat digunakan untuk menyelesaikan soal. Sesuai dengan penelitian Puspitasari (2016) kesalahan siswa dalam menyelesaikan soal diakibatkan oleh kemampuannya yang dapat dikatakan rendah dalam mengupas data, kemudian sikap kurang cermat dalam mengerjakan soal, lemahnya daya 
Vol 1 No 12020 Juli 2020

Jurnal AlphaEuclidEdu

pikir atau daya ingat siswa, lemahnya siswa dalam mengerti materi SPLDV dan lemahnya kemampuan siswa mentranslasikan bahasa soal ke dalam bahasa matematika.

Berdasarkan hasil wawancara, ketidakutuhan kemampuan siswa dalam menunjukkan indikator pemahaman konseptual dikarekan siswa masih sering lupa dan belum paham dengan konsep relasi dan fungsi, tidak paham maksud dari soal yang ditanyakan, tidak fokus saat belajar di dalam kelas, bahkan mengaku tidak pernah mengulang-ngulang materi pembelajaran matematika yang sudah diberikan oleh guru. Hal ini mengindikasikan bahwa pembelajaran matematika yang dialami siswa selama ini tidak bermakna. Pembelajaran bermakna ialah suatu cara menghubungkan informasi yang baru pada konsepkonsep yang berkaikan yang terdapat dalam struktur kognitif siswa. Struktur kognitif itu yakni fakta, konsep, dan generalisasi yang sudah dipelajari dan diingat oleh siswa (Ausubel dalam Dahar, 1996: 112). Hal demikian juga sejalan dengan pidato dari Menteri Pendidikan Republik Indoneisa, Nadiem Makarim, yang mengatakan bahwa "Kita memasuki era dimana masuk kelas tidak menjamin belajar." Sedangkan cara terbaik dalam belajar itu bukan hanya semata-mata kuat hafal pada konsep-konsep atau fakta-fakta belaka, namun belajar itu berupaya mengaitkannya agar mendapatkan pemahaman yang penuh, sehingga konsep yang dipelajari akan dimengerti secara benar dan mudah untuk diingat.. Selain itu kepedulian guru juga diperlukan dalam proses belajar di kelas. Guru yang mempunyai ikatan batin dengan siswa maka akan dapat menciptakan atmosfer belajar yang nyaman sehingga siswa merasa merdeka dalam belajar. Sehingga apabila hambatan epistemologi dapat diatasi, maka hambatan lainnya seperti hambatan didaktis dan ontogeni pun dapat terminimalisir.

\section{Kesimpulan}

Berdasarkan hasil analisis data pada tes pemahaman konseptual, secara umum dapat disimpulkan bahwa siswa kelas VIII F MTs Negeri 2 Pontianak mengalami hambatan epistemologi pada seluruh indikator pemahaman konseptual matematis. Dari 35 siswa, didapatkan hasil yaitu 40\% siswa masuk kedalam level 0 (prastruktural); 11,43\% siswa level 1 (unistruktural); $20 \%$ siswa level 2 (multistruktural); $25,71 \%$ siswa level 3 (relasional); dan 2,86\% siswa level 4 (extended abstract). Adapun hambatan yang dialami siswa pada level 0 yaitu pada semua indikator pemahaman konseptual. Siswa pada level 1 dan 2 mengalami hambatan pada indikator 2, 3, dan 4. Siswa pada level 3 mengalami hambatan pada indikator 2 dan 4. Siswa pada level 4 mengalami hambatan pada indikator 4.

\section{Referensi}

Biggs, J. \& Collis, K. 1982. Evaluating the Quality of Learning: The SOLO Taxonomy. New York: Academic Press.

Brousseau, G. (1997). Theory of Didactical Situation in Mathematics. Dordrecht: Kluwer Academic Publishers.

Manibuy, R., Mardiyana \& Saputro, D.R.S. 2014. Analisis Kesalahan Siswa dalam Menyelesaikan Soal Persamaan Kuadrat Berdasarkan Taksonomi SOLO pada Kelas X SMA Negeri 1 Plus di Kabupaten Nabire-Papua.Jurnal FKIP, 2(9): 933-945. Tersedia di http://digilib.uns.ac.id/ [diakses 11-08-2019]

NCTM. 2000. Principles and Standars for School Mathematics. Unitedd States of America: The National Council of Teachers of Mathematics, Inc.

Pegg, J. (1992). Assessing students' understanding at the primary and secondary level in the mathematical sciences. Reshaping assessment practice: Assessment in the mathematical sciences under challenge, 368-385.

Rasmania, R., Sugiatno, S., \& Suratman, D. Hambatan Epistimologis Siswa Dalam Menentukan Domain Dan Range Fungsi Kuadrat Di Sekolah Menengah Atas. Jurnal Pendidikan dan Pembelajaran, 7(7).

Suryadi, D. (2010). Didactical Design Research (DDR) dalam Pengembangan Pembelajaran Matematika. Makalah pada Seminar Nasional Matematika UNNES 